\title{
STRENGTHENING THE CHARACTER EDUCATION BASED ON SYED M. NAQUIB AL-ATTAS (A CASE OF STUDY OF AL-ISHLAH CIBINONG JUNIOR HIGH SCHOOL)
}

\author{
Merri Yulia. M¹, Galih Pratama ${ }^{2}$, Akhmad Alim ${ }^{3}$ \\ ${ }^{1}$ Universitas Ibn Khaldun Bogor \\ ${ }^{2}$ Institut Ummul Quro Al Islami \\ ${ }^{3}$ Universitas Ibn Khaldun Bogor \\ email: merriyulia12gmail.com \\ email: galih.pratama@iuqibogor.ac.id \\ email:ahmadalim09@yahoo.com
}

\begin{abstract}
The aim of National education is to create a generation that has good character and noble character. But 8 of 10 children experienced bullying cases in Indonesia stay on $4^{\text {th }}$ in cases of child abuse. Syed Muhammad Naquib Al-Attas as an educational figure in contemporary Islamic times. This study uses qualitative research methods with the type of library research. Strengthening Education forms good human character, Syed M. Naquib Al-Attas uses the concept of ta'dib, which is to instill good manners to form praiseworthy personalities in humans that encompass habits, character and habits. Strengthening character education at Al-Ishlah Cibinong Junior High School based on the Qur'an in planning, management, implementation and evaluation. Strengthening character education is highly needed in junior high schools by applying the model model, learning in class, integrating with all subject matter, integrating in Intrakulikuler, Kokurikuler and Extracurricular activities, empowerment and coaching.
\end{abstract}

\begin{abstract}
ABSTRAK
Tujuan pendidikan nasional adalah untuk mewujudkan generasi yang berakhlak mulia dan berakhlak mulia. Namun 8 dari 10 anak yang mengalami kasus bullying di Indonesia berada di urutan ke-4 dalam kasus kekerasan terhadap anak. Syed Muhammad Naquib Al-Attas sebagai tokoh pendidikan di zaman Islam kontemporer. Penelitian ini menggunakan metode penelitian kualitatif dengan jenis penelitian kepustakaan. Memperkuat Pendidikan membentuk karakter manusia yang baik, Syed M. Naquib Al-Attas menggunakan konsep ta'dib yaitu menanamkan budi pekerti untuk membentuk pribadi-pribadi terpuji pada manusia yang meliputi kebiasaan, budi pekerti dan kebiasaan. Penguatan pendidikan karakter di SMP Al-Ishlah Cibinong berbasis Al-Qur'an dalam perencanaan, pengelolaan, pelaksanaan dan evaluasi. Penguatan pendidikan karakter sangat dibutuhkan di sekolah menengah pertama dengan menerapkan model model, pembelajaran di kelas, mengintegrasikan dengan semua materi pelajaran, mengintegrasikan dalam kegiatan intrakulikuler, kokurikuler dan ekstrakurikuler, pemberdayaan dan pembinaan.

Keywords: education, caracter, manner, junior high school
\end{abstract}




\section{INTRODUCTION}

Education is one of several efforts in developing the potential of human reason. John Dewey expressed his opinion that education is a process of forming basic abilities, both related to the power of thought (intellectual) and the power of feeling (emotional) toward human habits. (Arifin, 2010: 3) Armai Arief cites Abdurrahman Saleh Abdullah's explanation that the goal of Islamic education built on three components of human nature such as body, spirit and mind. (Arief, 2002: 19)

Likewise in Indonesian constitution number 20 on 2003 season concerning the National Education System $3^{\text {rd }}$ clause:

National Education functions to develop capabilities and shape the character and civilization of a dignified nation in the context of educating the life of the nation, aiming at developing the potential of students to become people of faith and devotion to God Almighty, having noble, healthy, knowledgeable, capable, creative, independent and become democratic and responsible citizens. (2003, No. 20).

In that constitution there are several characteristics that must be exceeded by students in the implementation of education. But the reality in our society now as we have seen, we can say that education can be succeed in producing scientists and scholars, but in other cases it can be said that it has not succeeded in forming a generation of good character, because there are still many bad behaviors that occur in our society such as abuse of power, corruption, robbery, murder, sexual harassment and the rise of news about the use of drugs that not only caused self-destruction but also has an effect to others.

Based on suaramerdeka.com (2018) "The Unicef polling for 2014 stated that 8 of 10 children experienced bullying cases in Indonesia ranks on $4^{\text {th }}$ in cases of child abuse," said Commissioner of the Indonesian Child Protection Commission (KPAI) Jasra Putra, Friday (27/7).

Human character has to be well formed from an early age among at their home also at the school, because school is a place to gain knowledge and education in addition to education in the family. So it is fair if every parent is very selective in choosing a good school for their children. As explained by Daulay (2014: 75)

Schools, basically it has a goal to help parents at home in instilling good habits and character; schools also need to provide education to live in a society that has difficulty to get from their parents at home. Therefore, school education is actually related with family education, and it is also an advanced level of family education.

Some Islamic figures who studied character education and student morals, one of them Syed M. Naquib Al-Attas. His full name is Syed Muhammad Naquib ibn Ali ibn Abdullah ibn Muhsin al-Attas, or known as M. Naquib al-Attas. He was born on September 5, 1931 in Bogor, West Java. We can know about his lineage for thousands of years through the sayyid in Ba'alawi family in Hadramaut to Imam Hussein liniage, the grandson of the Prophet Muhammad. Among their ancestors there were guardians or ulemas', one of them from the mother's side was Syed M. al-Haydarus, teacher and spiritual guide Syed Abu Hafs Umar ba 
Syaiban from Hadramaut who took Nur al-Din al-Raniry one of famous 'ulama in Malay world to the rifa'iyyah order (Daud, 2011: 45). So Wan Daud (2003: 61) explains in his book:

Syed M. Naquib Al-Attas was a great Muslim thinker and his expertise began to be known in contemporary Islamic times. Syed M. Naquib Al-Attas's ideas are found in various disciplines, such as religion, education and science. His writings are considered the best and most creative in contemporary Islamic treasures. He was the first thinker in the Islamic world to define, conceptualize, and describe the meaning, scope and content of Islamic education, the ideas and methods of Islamization in contemporary science, the nature and establishment of Islamic universities, as well as the formulation and systematization of metaphysics, science and philosophy in science very systematic form.

One of the thoughts of Syed M. Naquib Al-Attas as explained by Baharudin (2007, p. 1):

With the development of the times, Muslims continue to be plagued by problems, especially in moral education for students and it is hoped that there is the best solution to deal with these problems. Judging from this problem, Al-Attas and Ibnu Miskawaih provide an analysis that what becomes a factor of students doing things that are not relevant to Islamic teachings is the lack of fostering the morals of students, both formal and informal.

Thus, it needs some appropriate solutions in strengthening character education and for students. The thinking of Syed M. Naquib Al Attas and the implementation of character education in Al-Ishlah Cibinong Junior High School below can be a choice of solutions for educators in carrying out the mandate to teach and educate their students in junior high schools.

\section{LITERATURE REVIEW}

Strenghtening in oxford dictionary is to become stronger; to make someone or something stronger Her position in the party has strengthened in recent weeks. Yesterday the yen strengthened against the dollar. The wind had strengthened overnight. The fall in unemployment is a sign of a strengthening economy.

Education is the process of inserting a culture into a person or society to make them civilized human beings. So education is a strategic tool in the formation of character (Muslich, 2011: 75).

The characters in the Indonesian dictionary (1989: 389) mean the mental, moral, or moral characteristics that distinguish one person from another. Whereas Narwati (2011: 1) explains that "Character taken from Greek is" character "which comes from the" kharassein "diction which means to carve or carve (to inscribe / to engrave), whereas from Latin" character "means to distinguish sign.

Character education is one of the efforts to foster human behavior towards the best standards based on values, norms of life and life. With this effort it becomes a solution to respect the perceptions and values of human person. And character education is centered on 
ethical values, but in practice character education includes strengthening important creativity including student social development (Majid and Andayani, 2011: 11). Therefore formed a commendable human being in the midst of society.

This character education should be instilled since childhood. The results of the research study showed 50\% of the variability of intelligence in adults had occurred when children were 4 years old. Then the next 30\% increase occurs when the age of 8 years. And 20\% left in the middle to the end of the second decade. From this theory it will be more optimal if character education starts from the family environment, which environment is the closest to the growth of children's character. (Muslich, 2011: 82)

Character education can also be interpreted as a process of inculcating good characters in all school members which includes a component of knowledge, awareness, or desire and behavior to carry out these things both to Allah SWT, himself, the surrounding community, and nationality to become a our people. (Samami and Hariyanto, 2011: 46)

\section{RESEARCH METHODOLOGY}

This research is a qualitative research that is through library research (library research), which is a type of research from the treasury of literature and makes "the world of text" as the main object of its analysis by writing, crediting, clarifying, reducing, and presenting data obtained from written sources. (Muhajir, 1989: 43)

This study examines the ideas and opinions expressed by Syed M. Naquib Al-Attas in character education obtained from books, magazines, newspapers, journals and other documents and also observations of character education in Al-Ishlah Cibinong Junior High School.

\section{RESULTS AND DISCUSSION}

\section{Strengthening Al-Qur'an Based Character Education Based On SMN Al-Attas}

There are several terms used to refer to the term "Islamic education" which is taken from Arabic (al-Qur'an) and al-sunnah. For example for the word tarbiyah, ta'lim, and ta'dib there is even a riyadlah. But in the following discussion the Naquib al-Attas version of Islamic education will be presented.

a. At-Ta'dib (The Purpose Of Character Education)

There are many terms used to refer to the notion of "Islamic education" which is taken from the Arabic pronunciation. For example the word tarbiyah, ta'lim, and ta'dib are even called riyadlah. The explanation for the concept of characeter education, Al-Attas is preferred to use the term ta 'dib, than other terms. The choice of ta 'dib, is the result of a separate analysis for al-Attas by analyzing from the side of the semantics and content which are adjusted to his moral messages. Even tarbiyah and ta 'lim have the most popularity, he places ta' dib as a concept which is more suitable with the concept of Islamic education. The word ta 'dib based on Al Attas, is a word that comes from addaba which means to give manners, or to 
educate. In al-Attas's view, by using the terms above, it can be understood that Islamic education is a process of internalization of manners in humans. So that the substantial content that occurs in Islamic education activities is the interaction that instills adab (Dr. Adian Husaini, 2013: 219-220) Al-Attas sees that adab is one of the main missions brought by the Messenger of Allah who is in contact with his people. By using these terms, it means reviving the sunnah of the Prophet. The conceptualization is as it says: "My Lord has educated me (addaba), thus making my education (ta'bett) the best." (HR. Ibn Hibban) (Ali ibn Hisamu alddin, tt: 406)

According from that hadith expression, that education is the main pillar to instill manners in humans, in order to succeed in life, both in this world and the hereafter. Therefore, Islamic education is intended as an important vehicle for the cultivation of knowledge that has pragmatic uses for people's lives. According to al-Attas, between science, charity and adab is an integrated whole (entity). The tendency to choose this term, for Al-Attas that education does not only speak the theoretical, but has direct relevance to the activities in which humans live. So, between science and charity must go hand in hand and in tune.

The concept of ta'dib in an Islamic perspective and referring to the concept of ta'dib offered by Syed Naquib al-Attas is the most appropriate concept for Islamic education, and not tarbiyah or ta'lim as used in the past. He said: "Ta"dib alredy includes within its conceptual structure the elements of knowledge (,ilm), instruction (ta $\left.{ }^{e c} \mathrm{lim}\right)$, and good breeding (tarbiyah). So that there is no need to refer to the concept of education in Islam as tarbiyah, ta "lim, ta ${ }^{e e}$ dib all together". ( Syed Muhammad Naquib al-Attas, 1993: .33)

In Islamic perspective, education has a role as a means to make humans embedded in the soul of Islamic values, not just limited to knowledge, in the end will make it a secular human being. In other words, Islam wants education as the goal of creating a better human being. Quoting from the opinion of Syed Naquib Al-Attas in his book Islam and Scularism, what needs to be determined in education is the value of man as a true human being, as a citizen of the city within himself, as a citizen in his micro kingdom, as a spiritual one, and thus what is emphasized is not the value of humans as physical entities measured in pragmatic and utilitarian contexts based on their usefulness to the state, society and the world (Syed Muhammad Naquib al-Attas, 1993: 141).

This means that perfect education should reflect systems that exist in humans. Because according to al-Attas, in humans there is an orderly and tidy system. It is like a systemized miniature of the universe. Then he took the form of the university as the highest institution that reflected this human system. According to him also, because the university is in charge of faculties, it must also describe universal human beings, not only interpreted as limited to their physical abilities, and in the end the formation of people free from values.

In this case al-Attas agreed with Al-Ghazali who said that spiritually, human reason is like a sincere and wise minister. His anger is like a policeman, while his lust is like an evil helper who can bring life to the whole city. If a king can rule well so that the minister's sincerity and wisdom can be utilized to keep the maid and the police in their proper place and 
work, the problems and city dwellers can be met fairly. Everything will describe the existence of rules and discipline. (Wan Mohd Nor Wan Daud: 208)

Therefore, man must make his intellect dominate other elements. The development of this ability is an important aspect in education as a process of cultivation of manners. This is why, that al-Attas portrays humans as miniatures of a university, because in it there are simultaneous faculties of one another.

As universal human beings according to him, that's a person who is able to display the attributes of God in his behavior and truly live out his essential unity with his divine form without losing his identity as a servant. This group of human beings is led by the Prophet Muhammad, followed by all the prophets and servants of His choice, namely aulia and scholars of scholarship and spiritual understanding is very deep. This opinion is in line with Ghazali who states, humans are instructed by God to imitate His nature (Takhaluq bi akhlaq Allah). The similarity here is, the similarity between God and humans lies in the similarity of traits, such as justice, kindness, and also love. As stated in his word, "Allah will make you a caliph on the face of the earth (QS 38: 26)", because of this perfection, Adam deserves to be God's representative. In terms of similarity here, al-Ghazali asserted, that the similarity of human nature with God does not mean showing equality or the union of human beings with God. (Masataka Takeshita, 2000: 3)

According to al-Attas, the value of human beings is influenced by the Islamic view that real people are portrayed by the figure of the Prophet Muhammad. And the principle of integral human unity according to Islam is the soul that has attained true knowledge about the problems of nature. Therefore, the mechanism of unity of the university community and the regulation of science is certainly not based on a myth about equality, but based on hierarchy according to the level of spiritual and moral achievement and educational ability. According to him, in an Islamic university the unifying element is science which has a position as a practical practice, and metaphysics as its core part. That is, that knowledge is sourced to the righteous is Allah.To form human beings that are the hope of the people, education are needed. So education is often positioned as being responsible for the complexity of life's problems, both personal and social problems, even the problems of the people. This paradigm departs from the assumption that the portrait and character of the people are very dependent or influenced by education. That is why both individuals and communities are often repatriated to the quality of education, education must have a social role, but that does not mean social problems can be resolved with education. (Mohammad Muslih, 1429: 101) This means putting social problems on the shoulders of education is an unfair attitude towards the world of education. And if forced, it will not only fail to solve the social problem, but, it is certain, that the world of education will be dragged down by the current problems of society which may threaten the world of education itself.

Understanding the concept of Islamic education in al-Attas's view uses the term (lafad) ta'dib, than the other terms. The choice of the term ta'dib is the result of a special analysis for al-Attas with an analysis of the semantics and composition that is adjusted to his moral 
messages. Even though the terms tarbiyah and ta'lim have taken root and were popularized, he placed ta'dib as a concept that was considered more in line with the concept of Islamic education.

According to Yunus, the word ta'dibit which was chosen by al-Attas, is a word (sentence) derived from the word addaba which means to give adab, or to educate. (Yunus and Qasim, 1972: 37-38)

\section{The Curriculum Of Islamic Education Based On Al Attas}

In the view of al-Attas, as quoted by Kholiq (1999: 275) it can be understood that Islamic education is a process of internalization and cultivation of manners in humans. So the substantial content that occurs in Islamic education activities is the interaction that instills manners. As stated by al-Attas, that Al-Attas's teaching and process saw that adab was one of the main missions brought by the Messenger of Allah who was in contact with his people. By using these terms, it means living the Sunnah of the Prophet. The conceptualization is as it says: "My Lord has educated me (addaba), thus making my education (ta'dib) the best (HR. Ibn Hibban).

According to al-Attas (1990: 22), between science, charity and adab is an integrated whole (entity). The tendency to choose this term, for al-Attas that education does not only speak the theoretical, but has direct relevance to the activities in which human's life. So, between science and charity must go hand in hand and in tune. Al-Attas has denied the term tarbiyah, as used by several pedagogical experts in the concept of Islamic education. He believes that the term tarbiyah is relatively new and is essentially reflected in the West.

Al-Attas also explained that the difference between ta'dib and tarbiyah is in the meaning of the substance. Tarbiyah emphasizes the aspect of affection (rahmah), while ta'dib, besides the rahmah dimension, also starts with the aspect of science. Basically, he acknowledged that with the concept of ta'dib, Islamic education means covering all elements of knowledge, teaching, and good nurturing. Therefore, outside the term ta'dib, for al-Attas there is no need to use it. An interpretation of the concept of ta'dib, al-Attas assumed that the human self is a subject that can be educated, made aware of its position as a cosmic creature. Emphasis on the aspect of etiquette is intended so that the knowledge obtained can be well practiced and not misused according to the free will of the owner of knowledge, because science is not free of value (value free) but full of value (value laden), namely Islamic values that require the perpetrators to practice for the sake of the interests and benefit of humanity.(Kholiq, 1999: 280-281)

Al-Attas's educational thinking is related to the foundations of philosophy including science, morality and education.

a. Science

According to al-Attas, knowledge comes from God that is obtained from the five physical and inner senses. The physical senses in the form of body taste, smell, tongue taste, vision, and hearing function to perceive particular things. While the inner senses relate to the physical senses which function to perceive sensory images and their 
meanings, unite and divide them, conceptualize ideas about them, store the results of absorption and carry out their intellections. The outer senses are the general senses, representations, estimates, memories and recollections as well as imagination. The integration of reason and intuition is a must in Islamic epistemology. Because, between the two elements above though different, that is, if reason refers to the intelligible things that are sought while intuition refers to the sensible things that are bestowed, but is the same element, meaning that if reason is one of the means of mental activity then intuition is also a the same thing. According to al-Attas, intuition comes to someone when it is ready, that is, when reason and experience are trained to accept and interpret it.

b. Morality and Education

One of the termonologies which is the main focus relating to education is the concept of din. The concept of din contains four meanings, namely indebtedness, submissiveness, judicious power, and tendency. This concept inherently contains faith, Islam and ihsan where ihsan is the integration between heart, mind and deeds in the form of obedience and loyalty to achieve the highest good. These three are the locomotive is science. There are at least two kinds of knowledge, the first is the knowledge that the way of acquisition is given by God, in the form of the Qur'an, alhadith, shari'ah, ladunni science, and wisdom in the form of knowledge and wisdom.

The concepts of knowledge and wisdom are closely related to morality and education. Wisdom according to al-Attas is the knowledge given by Allah for alim to apply it and wisdom so that justice arises. The embodiment of justice is nothing but the occurrence of manners in the lives of individuals and communities wherever he is.

Second, observation and research. This knowledge has a broad meaning, deductive and related to objects that have pragmatic value. As an implementation of this knowledge aims to form a good and civilized human being, not a good nation or country. Because if each human being is good, automatically the country or nation will also be good and civilized.

Whereas in the curriculum as a logical consequence of the two types of knowledge explained in the above educational concepts, namely the knowledge that is obtained from Allah SWT as well as research and observation knowledge, the curriculum used in his university is:

1) The religious sciences, including al-quran, al-sunnah, al-sharia, theology, Islamic metaphysics (Sufism), linguistic sciences such as Arabic, grammar, lexicography and literature.

2) Rational, intellectual and philosophical sciences which include humanities, nature, applied and technology. (Syamsul Nizar, 2002: 150)

The concept of character education according to Al-Attas can be seen on his opinions: The purpose of seeking knowledge in Islam is to inculcate goodness in man and individual self. The end of uducation in Islam is to produce a good man, and not---as in the case of westren civilization--- to produce a good man, and citizen. By ,good ${ }^{\text {ee }}$ in the concept of good 
man is meant precisely the man of adab in the sence here explained as encompassing the spiritual and material life of man.( Syed Muhammad Naquib al-Attas, 1995: 22)

Al-Attas assumed that the aim of Islamic education was to instill virtue in "the human self" as a human being and as an individual self. The ultimate goal of Islamic education is to produce good human beings, namely their material and spiritual life. In addition, the aim of Islamic education which focuses on the formation of individual personal aspects, also hopes that the formation of an ideal society is not overlooked. Ideally, al-Attas wants Islamic education to be able to produce good human beings universally (al-insan al-kamil). A goal that leads to two dimensions at once namely, as Abdullah (the servant of Allah), and as the Khalifah fi al-Ardl (God's representative on earth). Therefore, the Islamic education system must reflect the knowledge and behavior of the Messenger of Allah, and be obliged to realize Muslims who display the exemplary qualities of the Prophet Muhammad. With high hopes, alAttas wants that Islamic education can produce plenary human beings, human beings who are characterized by universalism in their insights and knowledge by reflecting on the example of the Prophet. Al-Attas's view of a good society, in fact cannot be separated from good individuals. So, one of the efforts to realize a good society, means the task of education must shape the personality of each individual as well. Because society is a collection of individuals. 3. Strengthening Character Education in Al-Ishlah Cibinong Junior High School

a. The Purpose Of Character Education According To SMPIT AL-ISHLAH

SMPIT Al-Ishlah has their vision and mission:

1) Vision

SMPIT Al-Ishlah Cibinong has a vision of 'Being the best Islamic Junior High School in educating students to be good people, noble, knowledgeable, characterized, independent, skilled and ready to enter further levels of education'

2) Mission

The mission of SMPIT AL-ISHLAH Cibinong are:

a) Building an educational environment that supports the realization of Islamic values in the lives of students both in schools, homes and the environment.

b) Carry out quality education activities by integrating mastery of science and technology and Imtaq that are aligned and complementary.

c) Form students into students who have academic and non-academic excellence, character, independent and skilled.

d) Realizing extracurricular activities that are programmed and in line with the vision of the school so that it supports the achievement of students in academic and nonacademic fields.

e) Implement active, creative, innovative, effective and fun learning strategies.

3) School Objectives

The objectives to be achieved at SMPIT Al-Ishlah Cibinong will be gradually monitored, evaluated, and controlled every 1 (one) year. The intended purpose is as follows: 
a) Achieved $100 \%$ graduation rate with an average value of 6.00 ;

b) Increasing the percentage of graduates who are accepted in public schools (SMA / SMK / MA) at least $25 \%$ of graduates;

c) Availability of standard learning media needed;

d) Implementation of the $3 \mathrm{~S}$ program (smile, greetings, greetings);

e) Implementation of the $7 \mathrm{~K}$ program (Security, Order, Beauty, Cleanliness, Comfort, Longing, Family) so that schools become conducive;

f) Implementation of optimal services to all parties that need based on SAS (School Administration System);

g) Establishing cooperation between families / extended families of the school and the surrounding environment;

h) have additional skills so that it will be very useful for students if they enter the workforce.

b. The Curriculum Of Character Education According To SMPIT AL-ISHLAH

As stated by the Headmaster of Al-Ishlah Cibinong Junior High School when interviewed by the writer on Thursday, January 10, 2019 and also reviewed in the curriculum guidelines published by the school that the character education program at Al-Ishlah Cibinong Junior High School is implemented in several components as follows:

1) Curriculum Contents

Strengthening character education is included in the material that must be taught and mastered and realized by students in everyday life. Character education is integrated into the subjects in the school as well as habituation in school culture. The teacher not only tries to meet the competency standards as mandated by the national curriculum, but also directs students accustomed to picking values from these subjects.

The focus of interviews conducted by researchers on the planning of character education Al-Ishlah Cibinong Junior High School namely relating to school planning in the management of character education, character education program planning (both short, medium, and long term planning programs), vision and mission of character education management and curriculum planning character building.

2) Learning and assessment process

Learning about character values is not only implemented at the cognitive level, but touches on internalization, as well as real practice in the daily lives of students in the community.

3) Subjects Management

Character education can be implemented in learning in every subject. Learning materials related to norms or character values in each subject need to be developed, made explicit, related to the context of daily life so that students better understand the values of these characters. 
4) School management

Character education in schools is also closely related to school management or management. The intended management is how character education is planned, implemented, and controlled in educational activities in schools adequately. The management includes, among others, values that need to be instilled, curriculum content, learning, assessment, educators and education staff, and other related components. Thus, school management is one of the effective media in character education in schools.

5) Implementation of personal development activities

Self-development activities that have been held by schools are one of the potential media for character building and academic quality improvement of students. Co-curricular and extracurricular activities are activities that can be carried out to assist the development of students in accordance with their needs, potential, talents, and interests through activities specifically organized by educators and / or educational staff who have the ability and authority at school. Through self-development activities are expected to develop the ability and sense of social responsibility, as well as the potential and achievements of students.

6) Strengthening character education outside the classroom.

According to the Principal and Vice-Principal in the Curriculum field, reinforcement of character education outside the classroom is carried out in various ways, namely:

a) Performing congregational prayers such as midday prayer.

b) Holding an honest canteen.

c) Organizing boxes for goods and finding money.

d) Instilling discipline of students to always dispose of trash in its place, come to school on time, take classes well in class, and others.

e)To foster students' responsibilities, a picket schedule is made to clean the classroom and the environment outside the classroom, and give group assignments.

f) Say hello and shake hands when meeting with teachers and friends.

\section{CONCLUSION}

1. Syed M. Naquib Al-Attas in the concept does not describe the strengthening of character education in schools. His concept of character education is mostly about ta'dib and how to create a good man. But his thoughts about Islamic education should be applied in strengthening character education in schools, especially for junior high schools, because at that age is the transition period of children to adults and the search for identity, therefore teachers as facilitators in schools need to understand and develop character and students as best as possible one of them with the concept of ta'dib from Syed M. Naquib Al-Attas.

2. Strengthening character education in SMPIT AL-ISHLAH Cibinong in general has followed the tarbaik sources that are based on the Qur'an in terms of planning, management, implementation, and also assessment. But obstacles remain in the 
implementation of character education itself, and therefore the school continues to communicate with higher institutions such as the UPT and the Office of Education.

\section{REFERENCES}

Al-Attas, Syed Muhammad Naquib (1990). Konsep Pendidikan dalam Islam, penerjemah Haidar Bagir. Bandung: Mizan

Daud, Wan Mohd Nor Wan. (1998). Filsafat Dan Praktik Pendidikan Islam Syed M.NaquibAl-Atas. Translators Hamid Fahmi, Arifin Ismail dan Iskandar Amel. Bandung: Mizan.

Husaini, Adian, (2013), Filsafat Ilmu perpektif Barat dan Islam. Jakarta: Gema Insani Press Kurniawan, Syamsul and Erwin Mahrus. 2013. Jejak Pemikiran Tokoh Pendidikan Islam. Yogyakarta: Ar-Ruzz Media.

Nata, Abudin. (2012). Pemikiran Pendidikan Islam dan Barat. Jakarta: Grafindo Persada

Naquib Al-Attas, Syed Muhammad. (1995), Prolegomena to The Metaphysics of Islam: an Exposition of The Fundamental Elements of The Worldview of Islam. Kuala Lumpur: ISTAC

Naquib Al-Attas, Syed Muhammad. (1993), The Concept of Education in Islam. a Frame work for an philosophy of education. Kuala Lumpur : Internasional Institute of Islamic Thought civilization (ISTAC)

Nizar, Samsul. (2002). Filsafat Pendidikan Islam. Jakarta: Ciputat Press.

Ramayulis and Samsul Nizar. 2005. Ensiklopedi Tokoh Pendidikan Islam. Ciputat: Ciputat Press Group.

Darmuin, et.al. (2012). Pendidikan dan Pelatihan Profesi Guru (PLPG) Kelompok Guru Kelas Madrasah Ibtidaiyah (MI). Semarang: Panitia PLPG LPTK Rayon 206 Fakultas Tarbiyah IAIN Walisongo.

Kholiq, Abdul dkk., (1999). Pemikiran Pendidikan Islam, kajian Tokoh Klasik dan Kontemporer, Yogyakarta: Pustaka Pelajar

Riyanto. (2010). 4 Model Penerapan Pendidikan Karakter di Sekolah: Antara Otonomi, Integrasi, Suplemen, dan Kolaborasi Read more about integrasi pendidikan karakter dengan mata pelajaran by Kang Marfu. https://riyantosma9yk.word press.com.

Yunus, Mahmud dan Qasim Bakri. (1972). Kitab al-Tarbiyah wa al-Ta'lim Juz 1A dan B. Ponorogo: Darussalam Press

https://www.suaramerdeka.com/news/baca/108547/bullying-urutan-keempat-kasus-kekerasananak-di-indonesia 